\title{
STUDY OF BENDING FATIGUE PROPERTIES OF Al-Si CAST ALLOY
}

\begin{abstract}
Fatigue properties of casting Al-alloys are very sensitive to the microstructural features of the alloy (e.g. size and morphology of the eutectic Si, secondary dendrite arm spacing - SDAS, intermetallics, grain size) and casting defects (porosity and oxides). Experimental study of bending fatigue properties of secondary cast alloys have shown that: fatigue tests up to $10^{6}-10^{7}$ cycles show mean fatigue limits of approx. 30-49 MPa (AlSi9Cu3 alloy - as cast state), approx. 65-76 MPa (AlSi9Cu3 alloy after solution treatment) and 60-70 MPa (self-hardened AlZn10Si8Mg alloy) in the tested casting condition; whenever large pore is present at or near the specimen's surface, it will be the dominant cause of fatigue crack initiation; in the absence of large casting defects, the influence of microstructural features (Si morphology; Fe-rich phases) on the fatigue performance becomes more pronounced.

Keywords: secondary Al-Si cast alloy, fatigue properties, fracture, cast defects
\end{abstract}

\section{Introduction}

The application of Al-Si alloy castings in many mechanical components, especially for cars and rail vehicles, has gradually increased in the last years, thanks to the great potential of these materials as replacements for ferrous alloys. Today an increasing amount of the aluminium going into producing new Al-alloy products is coming from recycled products. The increase in recycled metal becoming available is a positive trend, as secondary metal produced from recycled metal requires only about $2.8 \mathrm{kWh} / \mathrm{kg}$ of metal produced while primary Al-production requires about $45 \mathrm{kWh} / \mathrm{kg}$ of metal produced. It is to the Alindustry's advantage to maximize the amount of recycled metal, for both the energy-savings and the reduction of dependence upon overseas sources. Increasing the use of recycled metal is also quite important from the ecological standpoint, since producing aluminium by recycling creates only about $4 \%$ as much $\mathrm{CO}_{2}$ as by primary production [1-2].

It is recognized that these recycled Al-Si alloys are not likely to be suitable for fracture-critical components, where higher levels of Fe and Si have been shown to degrade fracture resistance. However the likelihood exists that they may perform quite satisfactorily in applications such as those listed where service life is determined by other factors [3]. The quality of recycled Al-Si casting alloys is considered to be a key factor in selecting an alloy casting for a particular engineering application [4].

$\mathrm{Al}-\mathrm{Si}-\mathrm{Cu}$ casting alloys have attracted much research interest as light-weight constructional materials in recent years, owing to their high castability, low density, low shrink rate, and relatively high specific strength [5]. These features make cast $\mathrm{Al}-\mathrm{Si}-\mathrm{Cu}$ alloys more attractive than other types of Al-alloys in the production of automotive components.

Self-hardening Al-alloys (e.g. AlZn10Si8Mg - zinc silumins) are an innovative class of Al-Si cast alloys that have high mechanical properties, which make them suitable for many applications in different industrial fields. The most important and relevant feature of the self-hardening alloys is related to their good performance, without the need of any heat treatment. The possibility to avoid heat treatment represents an important benefit, contributing to considerably reduce both the production cost of some components and the amount of energy involved in the manufacturing process [6-9].

However, to successfully utilize these secondary (recycled) $\mathrm{Al}-\mathrm{Si}(\mathrm{Cu}, \mathrm{Zn})$ alloys in automotive components, it is necessary to thoroughly understand its fatigue properties $[5,10]$. Numerous studies have shown that fatigue properties of conventional casting Al-alloys are very sensitive to casting defects and in most case both crack initiation lifetime and crack propagation lifetime are controlled by defects [5,10-13], secondary dendrite arm spacing (SDAS) values [5], as well as the presence of Fe-rich intermetallic phases (the Chinese-script-like $\alpha-\mathrm{Al}_{15}(\mathrm{Fe}, \mathrm{Mn})_{3} \mathrm{Si}_{2}$ phase and needle-like $\beta-\mathrm{Al}_{5} \mathrm{FeSi}$ phase) [14-16].

Pores are preferential sites for crack initiation in these alloys, and thus constitute the main factor influencing fatigue performance, independently of the loading conditions and of the stress applied. Compared with porosity, the eutectic structure (e.g. Si-morphology) and intermetallic phases play a minor role in crack initiation. The effect of porosity on fatigue life has

\footnotetext{
UNIVERSITY OF ŽILINA, FACULTY OF MECHANICAL ENGINEERING, UNIVERZITNÁ 8215/1, 01026 ŽILINA, SLOVAKIA

Corresponding author: Lenka.Kucharikova@fstroj.uniza.sk
} 
been summarized as follows: pores reduce the time for crack initiation by creating a high stress concentration in the material adjacent to the pores; because of this, most of the fatigue life is spent in crack growth. Porosity has been classified according to the importance of crack initiation as follows: a single shrinkage pore close to or at the surface is considered the most critical, whereas a gas pore at the surface is considered the least critical [5,10-17].

The present study is a part of larger research project, which was conducted to investigate and to provide better understanding properties of secondary Al-Si cast alloys. The main objective of this work was to study of bending fatigue properties in two secondary cast alloys (self-hardening AlZn10Si8MgMn alloy and age-hardening AlSi9Cu3 alloy).

\section{Experimental}

\subsection{Material}

As an experimental material the secondary (scrap-based - recycled) alloys were used: AlZn10Si8Mg (8.64Si-9.6Zn$0.005 \mathrm{Cu}-0.18 \mathrm{Mn}-0.45 \mathrm{Mg}-0.12 \mathrm{Fe}-0.002 \mathrm{Ni}-0.06 \mathrm{Ti}-0.001 \mathrm{Cr}-\mathrm{Al})$ and AlSi9Cu3 (9.4Si-1.0Zn-2.41Cu-0.25Mn-0.26Mg-0.9Fe$0.1 \mathrm{Ni}-0.05 \mathrm{Ti}-0.02 \mathrm{Sn}-0.04 \mathrm{Cr}-\mathrm{Al}$ ). Test bars (ø $20 \mathrm{~mm}$ with length $300 \mathrm{~mm}$ ) were produced by sand casting in foundry Zátor, Ltd. Czech Republic. The melt was not modified or refined. The chemical compositions of these alloys were carried out by using arc spark spectroscopy. Elements with contents of $0.001 \%$ or below are not explicitly listed. AlZn10Si8Mg cast alloy is a selfhardening alloy that is particularly used when good strength values are required without the need for heat treatment. With these alloy types, the mechanical properties are achieved after storage of approximately 7 to 10 days at room temperature. Particular attention should be paid to the high $0.2 \%$ yield strength. The low iron content has a particularly beneficial effect on the mechanical properties, which can also be traced to good fatigue strength. The sand casting alloy AlZn10Si8Mg achieves high values for tensile strength (220-250 MPa), offset $0.2 \%$ yield stress (190-230 MPa), however the low ductility limits (1-2\%) and hardness HB 90-100 [6-7]. AlSi9Cu3 cast alloy has lower corrosion resistance and is suitable for high temperature applications (dynamic exposed casts, where are not so big requirements on mechanical properties) - it means to max. $250^{\circ} \mathrm{C}$. The addition of $\mathrm{Cu}$ in the Al-Si alloy could strengthen the alloy via the precipitation of $\mathrm{Al}_{2} \mathrm{Cu}$ or via the modification of the brittle needlelike $\mathrm{Al}_{5} \mathrm{FeSi}$ phases. Copper improved the corrosion resistance of the alloy as well.

\subsection{Methods}

Casted semi-products (bars) were machined to produce fatigue test specimens (Fig. 1) with geometry according to ISO 1143. The gauge length diameter $\left(\mathrm{d}_{0}\right)$ was $8 \mathrm{~mm}$. All of the speci- mens were polished to minimize machining surface roughness effects on fatigue. Fatigue testing in rotating bending mode was carried out on a fatigue rotating bending at frequency $30 \mathrm{~Hz}$. The specimen were tested at temperature $20 \pm 5^{\circ} \mathrm{C}$ and under zero mean stress $\mathrm{R}=-1$.

AlZn10Si8Mg specimens were tested in as cast state after self-hardening, AlSi9Cu3 specimens were tested in as cast state and after heat treatment $\mathrm{T} 4$ (solution annealing at $525^{\circ} \mathrm{C}$ for 4 $\mathrm{h}$, water quenched at $40^{\circ} \mathrm{C}$ and natural aged at room tempera-

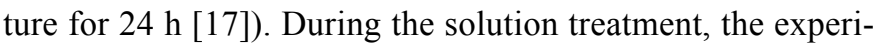
mental alloy is subjected to high temperatures for relatively long periods of time with two main objectives: first, to obtain maximum solubility and homogeneity of the alloying elements and impurities in the $\alpha$-matrix, and second, to modify the plate/ needle-like morphology of the eutectic Si to a less detrimental, rounded one.

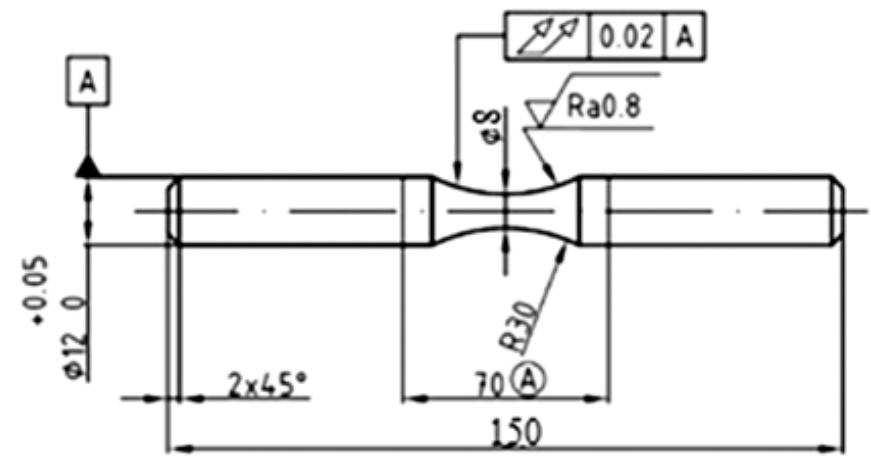

Fig. 1. Geometry and dimension of the specimen used in the study

The fatigue tests were conducted for different cyclic stresses based on S-N curves. Fatigue tests for the AlZn10Si8Mg specimens were carried out in the range of stress amplitudes from $100 \mathrm{MPa}$ to $60 \mathrm{MPa}$ and the fatigue limit was set to run-out number of cycles of $\mathrm{N}_{\mathrm{c}}=3 \times 10^{6}$. Fatigue tests for the untreated and heat treated $\mathrm{AlSi} 9 \mathrm{Cu} 3$ specimens were carried out in the range of stress amplitudes from $220 \mathrm{MPa}$ to $30 \mathrm{MPa}$ and the fatigue limit was set to run-out number of cycles of $\mathrm{N}_{\mathrm{c}}=1 \times 10^{7}$.

The samples for microscopic analysis were prepared by standards metallographic procedures [6]. For more detailed study of the morphology of the phases deep etching was applied. Microstructure were examined using an optical microscope (Neophot 32) equipped with a quantitative image analyzer (NIS-Elements 3.0.), and SEM (TESCAN VEGA II LMU) with a backscattered electron (BSE) mode, coupled with energydispersive X-ray (EDX) analysis. The chemical composition of the $\mathrm{Fe}$ - and $\mathrm{Cu}$-rich intermetallic phases was estimated by means of the EDX microanalysis. Porosity data (amount of volume porosity - \% vol.) were obtained by optical methods (determining the area of the material versus the area of the pores visible under the microscope) by image analysis, using the automatic software system NIS Elements 3.0. The fatigue fracture surfaces of experimental alloys were examined using SEM to identify the fatigue crack initiation sites. 


\section{Results and discussion}

\subsection{The microstructure analyses}

Typical microstructures of the experimental alloys are shown in Figs. 2-4. For more detailed study of the morphology of the phases was applied deep etching. During deep etching by $\mathrm{HCl} \alpha$-matrix is gradually etched (in all analysed Al-Si alloys) - Fig. 2b, Fig. 3b and Fig. 4b. The microstructure of recycled AlZn10Si8Mg cast alloy consists of $\alpha$-phase, eutectic (dark gray crystals Si in $\alpha$-phase) and variously type's intermetallic phases (Fig. 2a,b) [6-7]. The $\alpha$-matrix precipitates from the liquid as the primary phase in the form of dendrites and is nominally comprised of Al and Zn. Si-particles are like small grains of poorly rounded, thickened grains were observed on the periphery of dendrites $\alpha$-phase. Fe-containing intermetallics, such as $\mathrm{Al}_{5} \mathrm{FeSi}$ phases, are formed between the $\alpha$-dendrites. The $\mathrm{Al}_{5} \mathrm{FeSi}$ phase is a phase, having a $3 \mathrm{D}$-form of a platelet, which appears as needles in a 2D optical micrograph. AlFeMnSiNi or AlFeNi phases were observed in the form sharp-edged coarse gray particles. Addition of $\mathrm{Mg}$ to $\mathrm{Al}-\mathrm{Zn}-\mathrm{Si}$ alloys leads to formation two $\mathrm{Mg}$-intermetallic compounds: $\mathrm{Mg}_{2} \mathrm{Si}$ phase with skeleton-like or script-like so called "Chinese script" morphology (black phase) and ternary eutectic $\mathrm{Al}-\mathrm{Zn}_{2} \mathrm{Mg}-\mathrm{Cu}$. Colonies with oval round-compact like particles were detected by SEM as ternary eutectic. The sizes of the grains in this eutectic are very small and close to resolving power of the light microscopy. The typical microstructure of $\mathrm{AlSi} 9 \mathrm{Cu} 3$ alloy in as cast state (Fig. 3a,b) is constituted by dendrites of $\alpha$-phase, eutectic (dark grey eutectic Si-platelets in $\alpha$ - phase), Fe-rich phase $\mathrm{Al}_{15}(\mathrm{MnFe})_{3} \mathrm{Si}_{2}$ and $\mathrm{Cu}$-rich phase $\mathrm{Al}_{2} \mathrm{Cu}$, precipitated in the intercellular regions. Dominant $\mathrm{Al}_{15}(\mathrm{MnFe})_{3} \mathrm{Si}_{2}$ phase is black like skeleton or "Chinese script".

After heat treatment the relatively large eutectic Si platelets were spheroidized (about 90\%) in a more fine rounded shape smaller Si particles (Fig. 4a,b). The skeleton like $\mathrm{Al}_{15}(\mathrm{MnFe})_{3} \mathrm{Si}_{2}$ phase was fragmented to smaller skeleton particles. It was estab-
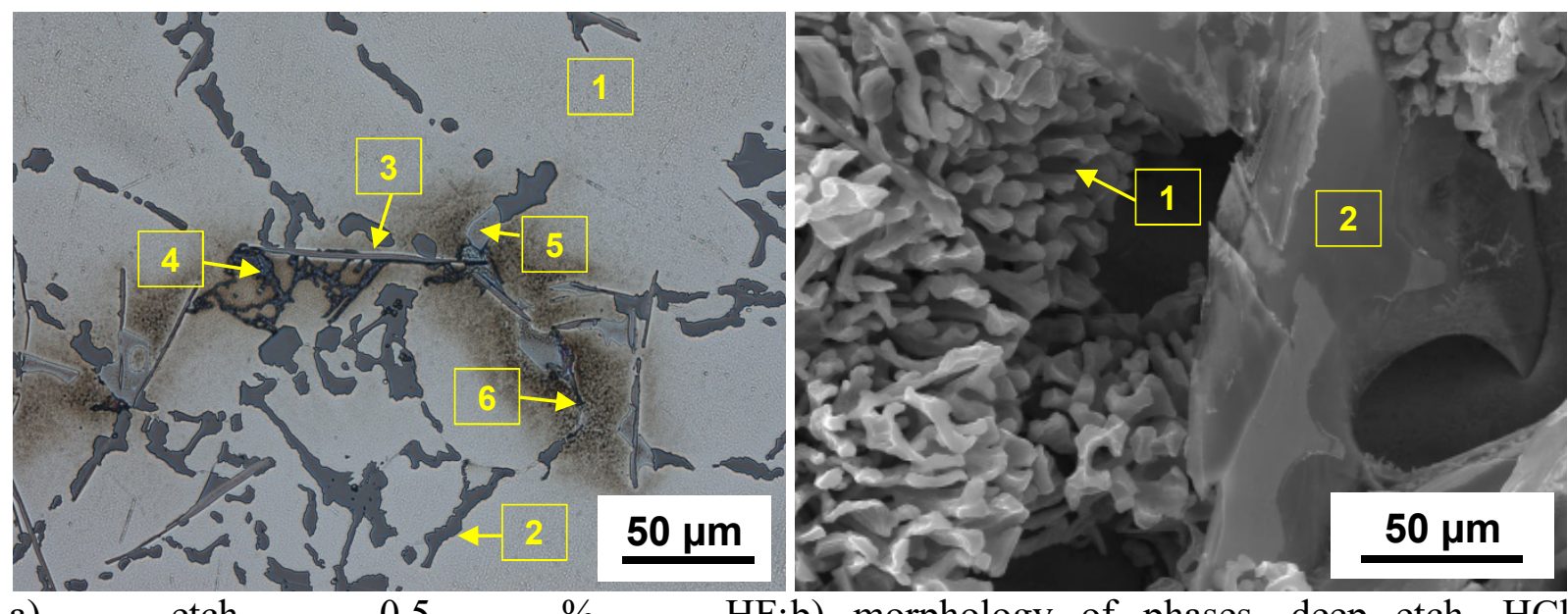

a)

etch.

0.5

$\mathrm{HF}:$ b) morphology of phases, deep etch. $\mathrm{HCl}$

1 - $\alpha$-matrix, $2-\mathrm{Si}, 3-\mathrm{Al}_{5} \mathrm{FeSi}, 4-\mathrm{Mg}_{2} \mathrm{Si}, 1-\mathrm{Si}, 2-\mathrm{Al}_{15}(\mathrm{FeMn})_{3} \mathrm{Si}_{2}$;

5 - AlFeMnSiNi or AlFeNi, 6-Al-Zn $2 \mathrm{Mg}-\mathrm{Cu}$;

Fig. 2. Microstructure of AlZn10Si8Mg cast alloy

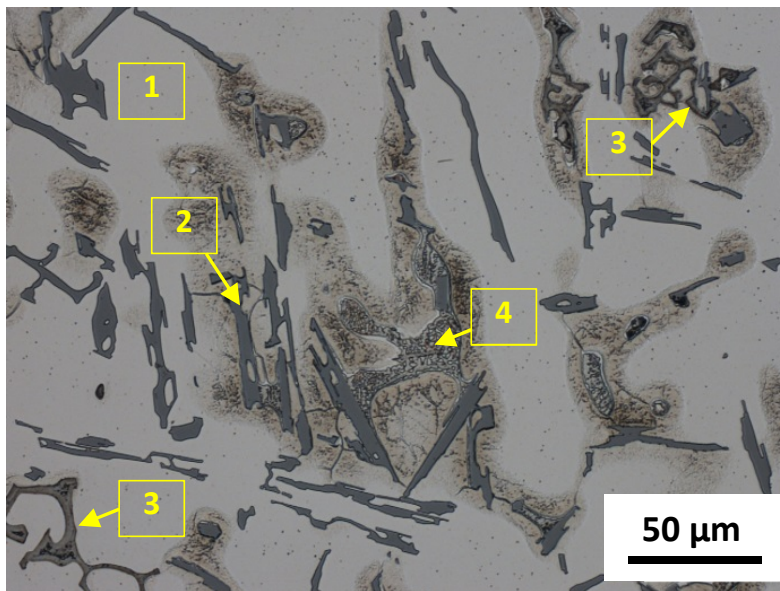

a) 1 - $\alpha$-matrix; 2 - $\mathrm{Si} ; 3-\mathrm{Al}_{15}(\mathrm{FeMn})_{3} \mathrm{Si}_{2} ; 4-\mathrm{Al}_{2} \mathrm{Cu}$; etch. Dix-Keller

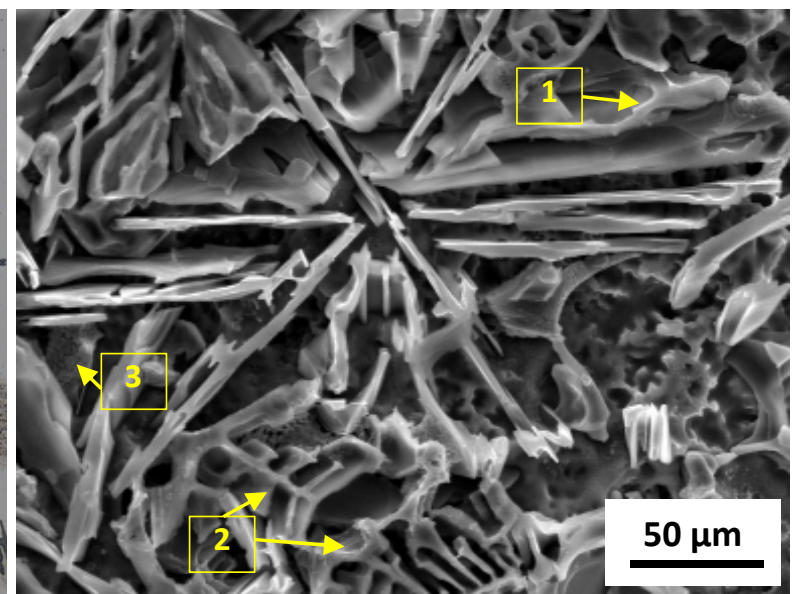

b) morphology of phases: deep. etch. $\mathrm{HCl1}$ - Si; 2 $\mathrm{Al}_{15}(\mathrm{FeMn})_{3} \mathrm{Si}_{2} ; 3-\mathrm{Al}_{2} \mathrm{Cu}$;

Fig. 3. Microstructure of AlSi9Cu3 cast alloy, as cast state 


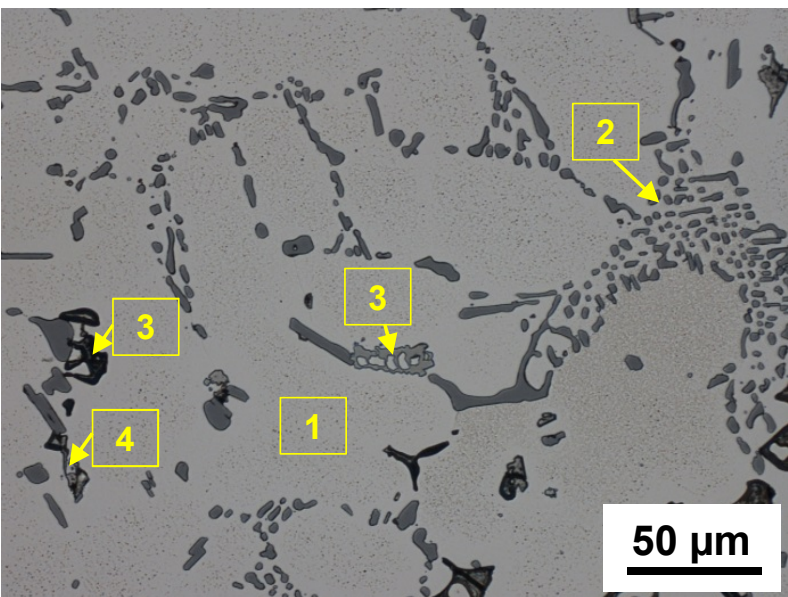

a) 1 - $\alpha$-matrix; 2 - $\mathrm{Si} ; 3-\mathrm{Al}_{15}(\mathrm{FeMn})_{3} \mathrm{Si}_{2}$, $4-\mathrm{Al}_{2} \mathrm{Cu}$; etch. Dix-Keller

Fig. 4. Microstructure of AlSi9Cu3 cast alloy, T4 heat treated

lished too, that the solution treatment was attended not only by fragmentation of $\mathrm{Al}_{15}(\mathrm{MnFe})_{3} \mathrm{Si}_{2}$ phase, but also by decreasing of area share of all $\mathrm{Fe}$-rich phases in $\mathrm{AlSi} 9 \mathrm{Cu} 3$ alloy. For nonheat treated state the area share of Fe-rich phases was c. $4.5 \%$ and for $525^{\circ} \mathrm{C}$ only c. $1.3 \%$.

The fatigue properties of an Al-Si alloy casting are controlled by a number of factors including the microstructural features of the alloy (size and morphology of the eutectic $\mathrm{Si}$ particles, secondary dendrite arm spacing - SDAS, intermetallics) and casting defects (porosity and oxides) present in the casting. Surface porosity plays an important role in determining fatigue life in view of the fact that the fatigue life decreases with an increase in the surface porosity/pore size, and vice versa. Impurities in the form of inclusions (first of all of needle-like brittle phases $\mathrm{Al}_{5} \mathrm{FeSi}$ ) can also affect the fatigue properties [18-20].

Solidification rate significantly influenced volume fraction and size of the solidification defects (in the form of gas pores and shrinkages cavities). The observed difference in the distribution of shrinkage pores (groups of pores surrounded by

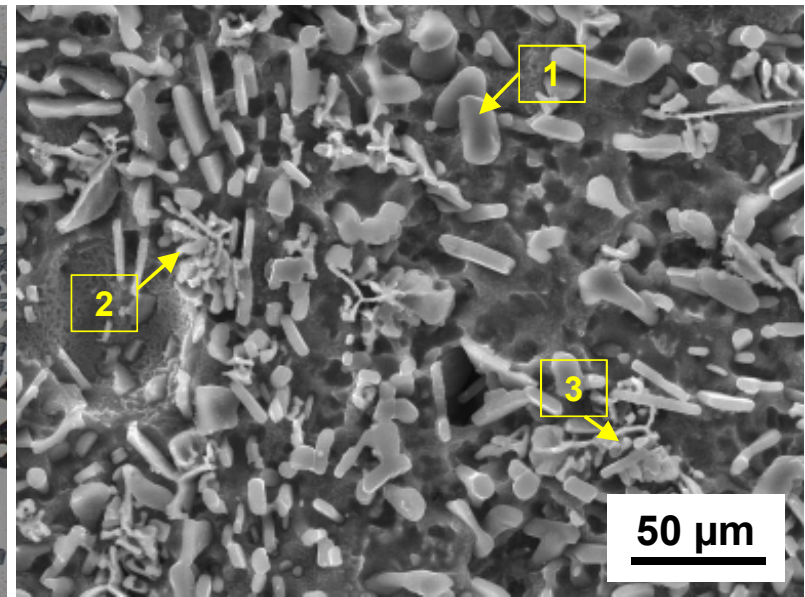

b) morphology of phases: deep. etch. $\mathrm{HCl}$ 1 - $\mathrm{Si} ; 2-\mathrm{Al}_{15}(\mathrm{FeMn})_{3} \mathrm{Si}_{2}, 3-\mathrm{Al}_{2} \mathrm{Cu}$;

primary dendrites and eutectic phase) and gas pores (isolated) can be used to differentiate between the two types of porosity. The cast defects distribution is in both alloys heterogeneous as can be seen in the optical micrographs in Fig. 5. The average pore density ( $\%$ vol.) of AlZn $10 \mathrm{Si} 8 \mathrm{Mg}$ was measured about $5 \%$ and of $\mathrm{AlSi} 9 \mathrm{Cu} 3$ about $8 \%$.

\subsection{Fatigue properties}

Results of the fatigue tests are shown in Fig. 6, where the numbers of cycles to fracture is plotted against the stress amplitude for the self-hardening AlZn10Si8Mg specimens and $\mathrm{AlSi} 9 \mathrm{Cu} 3$ as-cast and T4 heat treated specimens. Markers with arrows indicate specimens that did not fail before the maximum number of cycles (run-out).

The as-cast AlSi9Cu3 specimens were tested first to provide a baseline on fatigue life. The fatigue life increased with decreasing total strain amplitudes for all the experimental alloys.

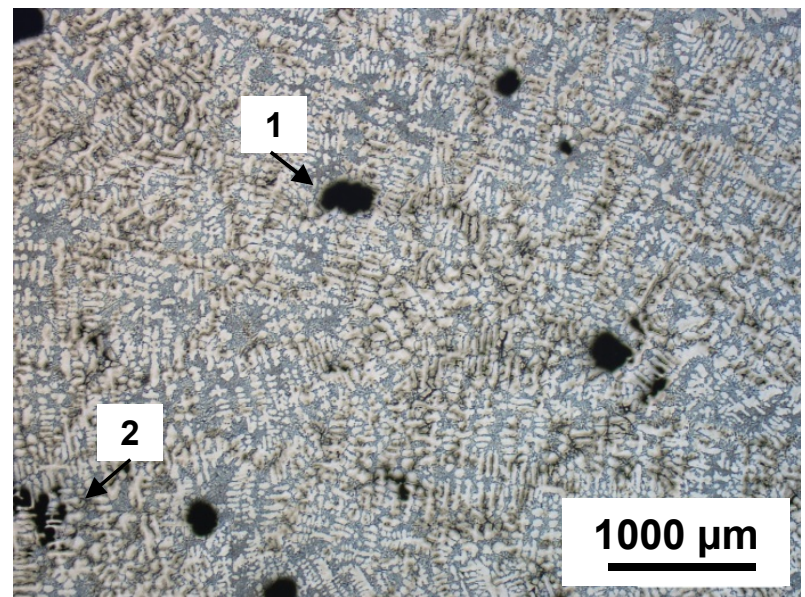

a) AlZn10Si8Mg alloy, etch. 0.5\% HF:1 - gas pores, 2 - microschrinkage

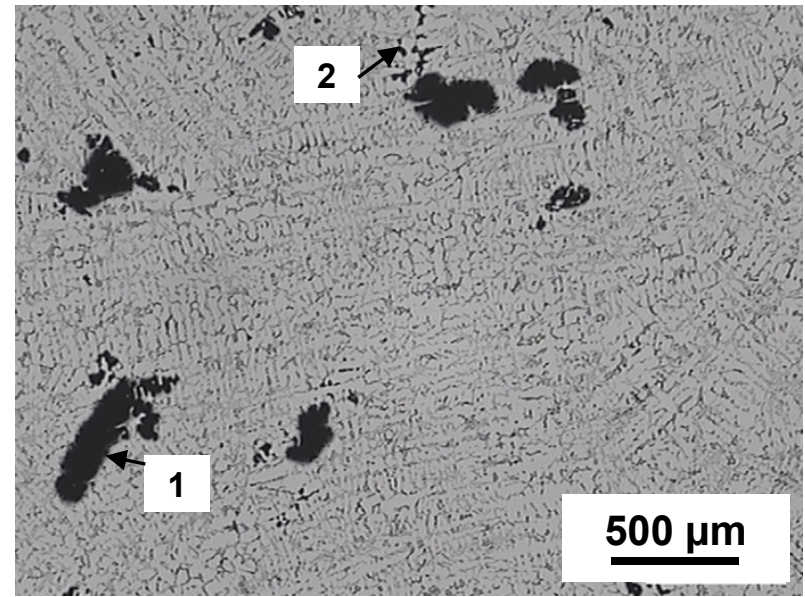

b) AlSi9Cu3 alloy, etch. Dix-Keller 1 - gas pores, 2 - microschrinkage

Fig. 5. Porosity of experimental material 

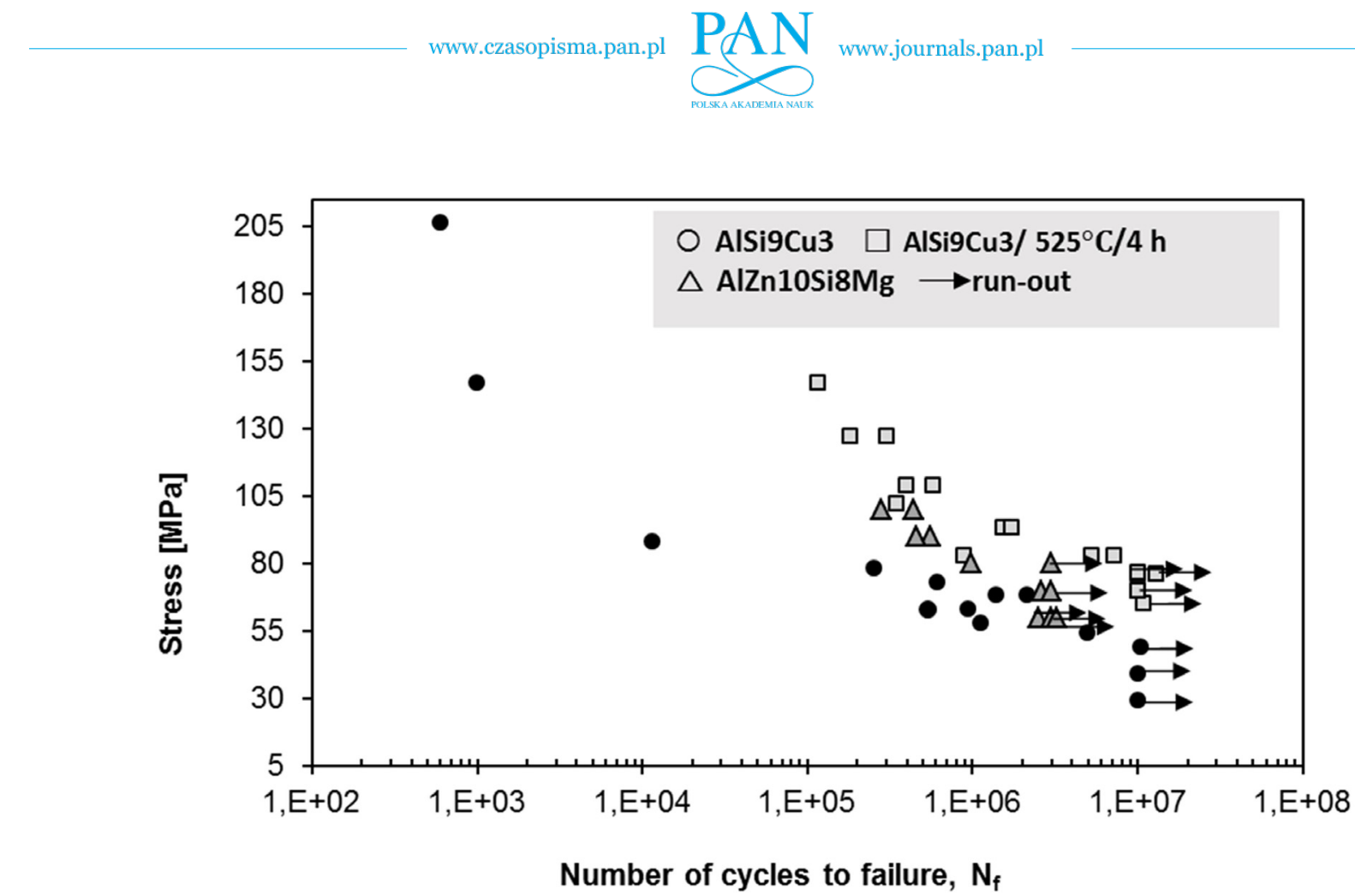

Fig. 6. The standard $\mathrm{S} / \mathrm{N}$ fatigue curve of the experimental aluminium alloys

All investigated alloys show a pronounced fatigue limit. The mean fatigue limits are $40 \pm 10 \mathrm{MPa}$ (AlSi9Cu3 - as cast state), $70 \pm 5.5 \mathrm{MPa}$ (AlSi9Cu3 - T4) and $65 \pm 5 \mathrm{MPa}(\mathrm{AlZn10Si8Mg}-$ selfhardened). T4 heat treatment increases the fatigue strength of the specimens markedly. It is evident, that after solution treatment $\left(525^{\circ} \mathrm{C} / 4 \mathrm{~h}\right)$ the fatigue limit increases thanks to spheroidization of eutectic $\mathrm{Si}$. The growth in fatigue strength with respect to the temperature of solution treatment is c. $57 \%$ respectively.

The global view of the fatigue fracture surface for al tested specimens is very similar. The process of fatigue consists of crack initiation stage, progressive crack growth across the specimen and final sudden static fracture [5,21-22]. Typical high cycle fatigue fracture surface of specimen is represented transcrystalline fatigue failure. The fracture was obtained to initiate microvoids at the subsurface of the specimen leading to the formation of local micro-cleavage facets. Porosity on the fracture surface was quantified in terms of their projected areas, lengths, and the depth from the sample free surface, as illustrated in Fig. 7. An observation of the crack initiation site indicates that fatigue cracks always nucleate from casting defects (such as pores or shrinkage cavities) located at or near the surface (Figs. 7a,b). The fatigue data corresponding with pores size and morphology. Also the fatigue life decreases significantly as the surface pore size increases. The initiating pores were observed to be generally large. The initiating pore diameters fall in the range of $100 \mu \mathrm{m}$ to $1.650 \mu \mathrm{m}$. The main micrographic characteristics of the fatigue fracture near the initiating site are the tear ridges (Fig. 8a) in the direction of the crack propagation. In the crack propagation regions the presence of fatigue striations is visible (Fig. 8b) as well as secondary microcracks due to the Si particles debonding. The fatigue striations generated via a repeated plastic blunting-sharpening process.

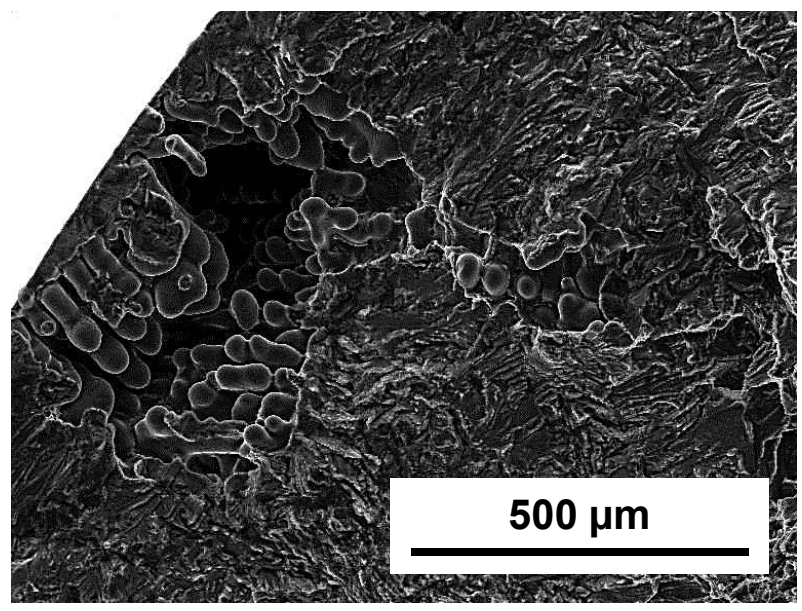

a) cast defect

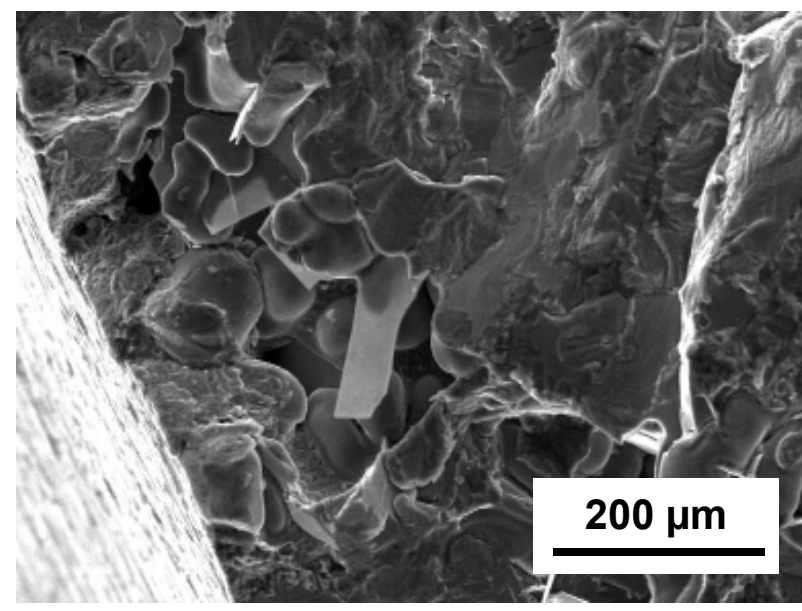

b) cast defect with Fe-plate-like phases

Fig. 7. Detail of crack initiation 


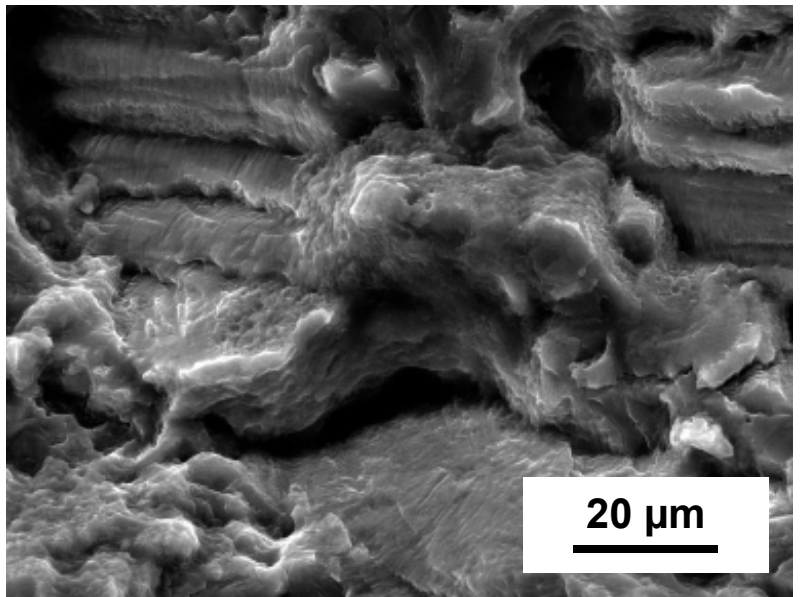

a) fatigue fracture surface near the initiating site - fine tear ridges

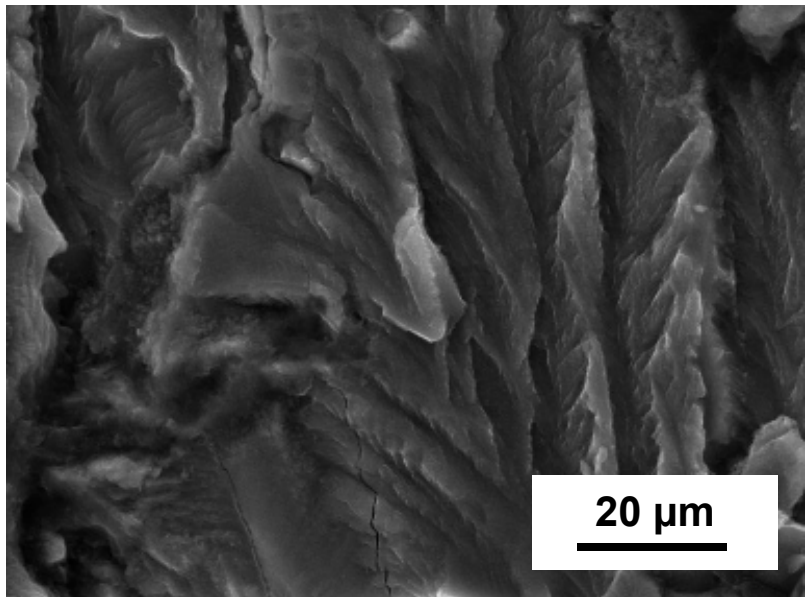

b) fatigue striations and secondary microcracks

Fig. 8. SEM images of the fatigue fracture surface of AlZn10Si8Mg cast alloy

\section{Conclusion}

Fatigue bending properties of secondary Al-Si cast alloys was investigated and following conclusions could be drawn: the fatigue limits was determined $40 \pm 10 \mathrm{MPa}$ (AlSi9Cu3 - as cast state), $70 \pm 5.5 \mathrm{MPa}$ (AlSi9Cu3 - T4 heat treatment) and $65 \pm 5 \mathrm{MPa}$ (AlZn10Si8Mg - self-hardened). T4 heat treatment increases the fatigue strength of the specimens markedly. Fatigue properties of the self-hardened alloy are comparable with T4 heat treated alloy. The most probably place of crack initiation is surface porosity, which is the most casting defects affecting the fatigue life. Fatigue life increases if initiation places reduce in number. An increase in pore size seems to reduce fatigue life too. The initiating pore diameters fall in the range of $100 \mu \mathrm{m}$ to $1650 \mu \mathrm{m}$. Fatigue crack propagation was mainly characterized by fatigue striations in conjunction with some secondary cracks.

\section{Acknowledgement}

Financial support received from Slovak Research project VEGA n $1 / 0533 / 15$ is gratefully acknowledged

\section{REFERENCES}

[1] K.S. Das, J.A.S. Gren, JOM 62 (2), 27-31 (2010).

[2] L. Kuchariková, E. Tillová, O. Bokůvka, Transport Problems 11 (2), 117-122 (2016).

[3] J.A. Taylor, Procedia Materials Science 1, 19-33 (2012).

[4] E. Tillová, M. Chalupová, L. Hurtalová, E. Ďuriníková, Manufacturing Technology 11, 70-76 (2011).

[5] K.L. Fan, X.S. Liu, G.Q. He, H. Chen, Mater. Sci. Eng. A. 632, 127-136 (2015)
[6] E. Tillová, E. Duriníková, M. Chalupová, Acta Metallurgica Slovaca 17 (1), 4-10 (2011).

[7] E. Tillová, M. Chalupová, L. Hurtalová, J. Belan, Manufacturing Technology 15 (4), 720-727 (2015).

[8] J. Pezda, Archiwes of Foundry Engineering. 13 (1), 143-146 (2013).

[9] M. Rosso, I. Peter, C. Castella, R. Molina, Mater. Today: Proceedings 2 (10), 4949-4956 (2015).

[10] R. González, A. González, J. Talamantes-Silva, S. Valtierra, R.D. Mercado-Solís, N.F. Garza-Montes-de-Oca, R. Colás, Int. J. Fatigue 54, 118-126 (2013).

[11] H.R. Ammar, A.M. Samuel, F.H. Samuel, Mater. Sci. Eng. A. 473, 58-64 (2008).

[12] H.R. Ammar, A.M. Samuel, F.H. Samuel, Mater. Sci. Eng. A. 473, 65-75 (2008).

[13] H.R. Ammar, A.M. Samuel, F.H. Samuel, Int. J. Fatigue 30, 10241035 (2008).

[14] L. Ceschini, I. Boromei, A. Morri, S. Seifeddine, I.L. Svensson, Materials and Design 36, 522-528 (2012).

[15] P. Huter, P. Renhart, S. Oberfrank, M. Schwab, F. Grün, B. Stauder, Int. J. Fatigue 82, 588-601 (2016)

[16] J.Z. Yi, Y.X. Gao, P.D. Lee, T.C. Lindley, Mater. Sci. Eng. A. 386, 396-407 (2004).

[17] S.K. Shaha, F. Czerwinski, W. Kasprzak, J. Friedman, D.L. Chen, Int. J. Fatigue 70, 383-394 (2015)

[18] A. Fabrizi, S. Ferraro, G. Timelli, Mater. Charact. 85, 13-25 (2013).

[19] P. Kopas, M. Sága, Manufacturing Technology 13 (1), 59-64 (2013).

[20] P. Szataniak, M. Mazur, R. Ulewicz, F. Nový, Komunikácie 18 (1), 89-92 (2016)

[21] L. Dietrich, J. Radziejewska, Materials and Design 32, 322-329 (2011).

[22] M. Warmuzek, Aluminum-silicon casting alloys: an atlas of microfractographs. ASM International, USA (2004). 